\title{
Tributyltin(IV) Butyrate: A Novel Epigenetic Modifier with ER Stress- and Apoptosis-Inducing Properties in Colon Cancer Cells
}

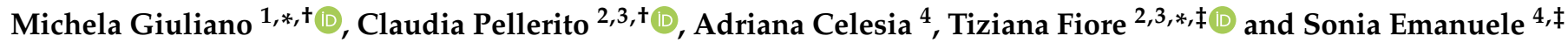 \\ 1 Dipartimento di Scienze e Tecnologie Biologiche Chimiche e Farmaceutiche (STEBICEF), \\ Università degli Studi di Palermo, Plesso di Biochimica, Via del Vespro 129, 90127 Palermo, Italy \\ 2 Dipartimento di Fisica Chimica-Emilio Segrè (DiFC), Università degli Studi di Palermo, Viale delle Scienze, \\ Ed. 17, 90128 Palermo, Italy; claudia.pellerito@unipa.it \\ 3 CIRCMSB-Consorzio Interuniversitario di Ricerca in Chimica dei Metalli nei Sistemi Biologici, \\ Via Celso Ulpiani, 27, 70125 Bari, Italy \\ 4 Dipartimento di Biomedicina, Neuroscienze e Diagnostica Avanzata (BIND), Università degli Studi di Palermo, \\ Via del Vespro 129, 90127 Palermo, Italy; adriana.celesia@unipa.it (A.C.); sonia.emanuele@unipa.it (S.E.) \\ * Correspondence: michela.giuliano@unipa.it (M.G.); tiziana.fiore@unipa.it (T.F.) \\ $\dagger$ These Authors equally contributed to this paper as first Author. \\ $\ddagger$ The Authors share senior co-authorship.
}

\section{check for} updates

Citation: Giuliano, M.; Pellerito, C.; Celesia, A.; Fiore, T.; Emanuele, S. Tributyltin(IV) Butyrate: A Novel Epigenetic Modifier with ER Stressand Apoptosis-Inducing Properties in Colon Cancer Cells. Molecules 2021, 26, 5010. https://doi.org/10.3390/ molecules 26165010

Academic Editors: Loredana Salerno, Sebastiano Intagliata and Jean-Marc Sabatier

Received: 30 June 2021

Accepted: 14 August 2021

Published: 19 August 2021

Publisher's Note: MDPI stays neutral with regard to jurisdictional claims in published maps and institutional affiliations.

Copyright: (c) 2021 by the authors Licensee MDPI, Basel, Switzerland. This article is an open access article distributed under the terms and conditions of the Creative Commons Attribution (CC BY) license (https:/ / creativecommons.org/licenses/by/ $4.0 /)$.
Abstract: Organotin(IV) compounds are a class of non-platinum metallo-conjugates exhibiting antitumor activity. The effects of different organotin types has been related to several mechanisms, including their ability to modify acetylation protein status and to promote apoptosis. Here, we focus on triorganotin(IV) complexes of butyric acid, a well-known HDAC inhibitor with antitumor properties. The conjugated compounds were synthesized and characterised by FTIR spectroscopy, multi-nuclear $\left({ }^{1} \mathrm{H},{ }^{13} \mathrm{C}\right.$ and $\left.{ }^{119} \mathrm{Sn}\right) \mathrm{NMR}$, and mass spectrometry (ESI-MS). In the triorganotin(IV) complexes, an anionic monodentate butyrate ligand was observed, which coordinated the tin atom on a tetra-coordinated, monomeric environment similar to ester. FTIR and NMR findings confirm this structure both in solid state and solution. The antitumor efficacy of the triorganotin(IV) butyrates was tested in colon cancer cells and, among them, tributyltin(IV) butyrate (BT2) was selected as the most efficacious. BT2 induced G2/M cell cycle arrest, ER stress, and apoptotic cell death. These effects were obtained using low concentrations of BT2 up to $1 \mu \mathrm{M}$, whereas butyric acid alone was completely inefficacious, and the parent compound TBT was poorly effective at the same treatment conditions. To assess whether butyrate in the coordinated form maintains its epigenetic effects, histone acetylation was evaluated and a dramatic decrease in acetyl- $\mathrm{H} 3$ and $-\mathrm{H} 4$ histones was found. In contrast, butyrate alone stimulated histone acetylation at a higher concentration $(5 \mathrm{mM})$. BT2 was also capable of preventing histone acetylation induced by SAHA, another potent HDAC inhibitor, thus suggesting that it may activate HDACs. These results support a potential use of BT2, a novel epigenetic modulator, in colon cancer treatment.

Keywords: triorganotin(IV) butyrates; colon cancer; histone acetylation; apoptosis; ER stress; HDAC inhibitors

\section{Introduction}

Organotin(IV) carboxylates possess significant properties such as antibacterial and antifungal agents and display promising antitumor activity [1,2]. Every year, new organotin(IV) carboxylate complexes are synthesized with the aim of improving the anticancer potential of their parental compounds and to find a valid alternative to classical chemotherapeutics that induce serious side effects in patients [3]. In particular, the carboxylic function has been used as an anchor for the tin, leaving the "biological" tasks to other functional groups. 
Short-chain fatty acids are naturally occurring fatty acids, and exhibit various pharmacological applications [4-7]. Since 1860, complexes of organotins with short chain fatty acids have been produced and chemically characterised $[8,9]$.

More recently, Nath has described organotin(IV) complexes with lauric, myristic, and stearic acids through spectroscopic studies [10].

For a long time, we have been involved in organotin(IV) complex synthesis, characterization, and biological studies to test their potential anti-tumor efficacy [11-16]. The leitmotiv has been the modulation of the intrinsic organometallic moiety cytotoxicity by means of biologically related molecules (synthetic or natural). Such a modulation is usually achieved by two (often overlapping) routes: by dampening the damaging effects of the metal core and by serving as a carrier for specific tissue districts.

In this work, butyric acid was chosen for its well-known histone deacetylase inhibitory activity, which is strictly correlated with its anti-tumor properties [17].

Butyric acid belongs to short-chain fatty acid class produced by the anaerobic fermentation of dietary fibres in the human colon. Beyond its metabolic function sustaining normal colonocytes, it has been shown to inhibit growth and to induce differentiation of colon cancer cells as well as a variety of other tumor cell types [17]. Butyrate has also been shown to induce apoptosis in tumor cells, an effect which is usually displayed at $\mathrm{mM}$ range concentration and which is related with histone hyperacetylation due to histone deacetilase (HDAC) inhibition. However, other mechanisms including butyrate-induced DNA methylation inhibition and post-translational modifications of specific proteins have been reported [18].

Butyrate has also been shown to potentiate the effects of traditional chemotherapeutics such as 5-fluorouracil (5-FU), vincristine, adryamycine, methotrexate, and cisplatin [19-22]. However, these potentiating effects have also been observed using relatively high concentrations of butyrate.

Considering the low efficacy of butyrate compared to that of the new generation of HDAC inhibitors that have had an impact on epigenetic tumor-targeted therapy [23], we focused on butyrate organotin conjugates to improve its efficacy and to understand whether it maintains its epigenetic properties in colon cancer cells.

Histone modifications provide an important mechanism of epigenetic regulation [24,25] and many organotin compounds may influence epigenetics as well. For instance, evidence has been provided that organotin compounds are capable of affecting histone acetyl transferase (HAT) activity [26] or modifying DNA methylation pattern [27,28].

Our previous studies have clearly shown that organotin complexes with valproic acid, another HDAC inhibitor, exert a remarkable antitumor action in hepatocarcinoma cells, as well as the dibutyltin(IV) complex of caffeic acid [13,15].

Promising results have been obtained with butyrate-releasing prodrugs and butyrate derivatives, rather than with butyrate itself [29-31]. In line with these findings, this paper describes triorganotin(IV) butyrates synthesis and its characterization, and provides a biological evaluation of their efficacy in colon cancer cells. Specifically, tributyltin(IV) butyrate was chosen as the most promising compound and its proapoptotic and epigenetic action are described.

\section{Results and Discussion}

\subsection{Synthesis and Characterization of Triorganotin(IV) Butyrates}

The analytical data revealed the formation of compounds with a 1:1 metal-to-ligand ratio, leading to formula $\mathrm{R}_{3} \mathrm{SnBT}, \mathrm{R}=\mathrm{Me}(\mathrm{BT} 1), \mathrm{Bu}(\mathrm{BT} 2), \mathrm{Ph}(\mathrm{BT} 3)$, and $\mathrm{BT}=$ butyrate.

The structures of the synthesized compounds were confirmed by spectroscopic analyses. The coordinating mode of butyric acid towards the triorganotin(IV) moiety can be inferred by comparing the infrared spectroscopy (IR) spectra of free and coordinated ligands. The vibrational frequencies of $\mathrm{OCO}, \mathrm{Sn}-\mathrm{C}$, and $\mathrm{Sn}-\mathrm{O}$ moieties are taken into consideration. These frequencies provide useful information to identify the coordination around tin. In the free ligand, the $\mathrm{C}=\mathrm{O}$ stretching of the carboxylic group was observed at 
$1712 \mathrm{~cm}^{-1}$. This band disappears upon coordination, indicating deprotonation of the carboxylic group. The characteristic absorption signals of carboxylate group for $\mathrm{R}_{3} \mathrm{Sn}$ butyrate $\left(\mathrm{R}=\mathrm{Me}, \mathrm{BT1}\right.$; Bu, BT2; and Ph, BT3) were assigned in the range of $1565-1574 \mathrm{~cm}^{-1}$ for asymmetric stretching and $1338-1345 \mathrm{~cm}^{-1}$ for symmetric stretching frequencies. $\Delta v$ values $\left(=v_{\mathrm{asCOO}}{ }^{-}-v_{\mathrm{sCOO}}{ }^{-}\right)$ranging from 220 to $236 \mathrm{~cm}^{-1}$ are characteristic for coordinated ester-type carboxylate groups [32,33].

A band in the region of $488-495 \mathrm{~cm}^{-1}$ was assigned to $v(\mathrm{Sn}-\mathrm{O})$, which supports the bonding of the carboxylate group to the tin atom. The observed $v(\mathrm{Sn}-\mathrm{C})$ frequencies in trialkyltin(IV) derivatives (508-545 $\mathrm{cm}^{-1}$ ) and triphenyltin(IV) derivative (at $454 \mathrm{~cm}^{-1}$ ) correspond to the reported values [34-36].

In conclusion, the infrared data suggested a monoanionic monodentate coordination of an unidentate ester-type COO group to the $\mathrm{R}_{3} \mathrm{Sn}(\mathrm{IV})$ moiety tin(IV) atom, resulting in tetra-coordinated, monomeric environment (Figure 1).

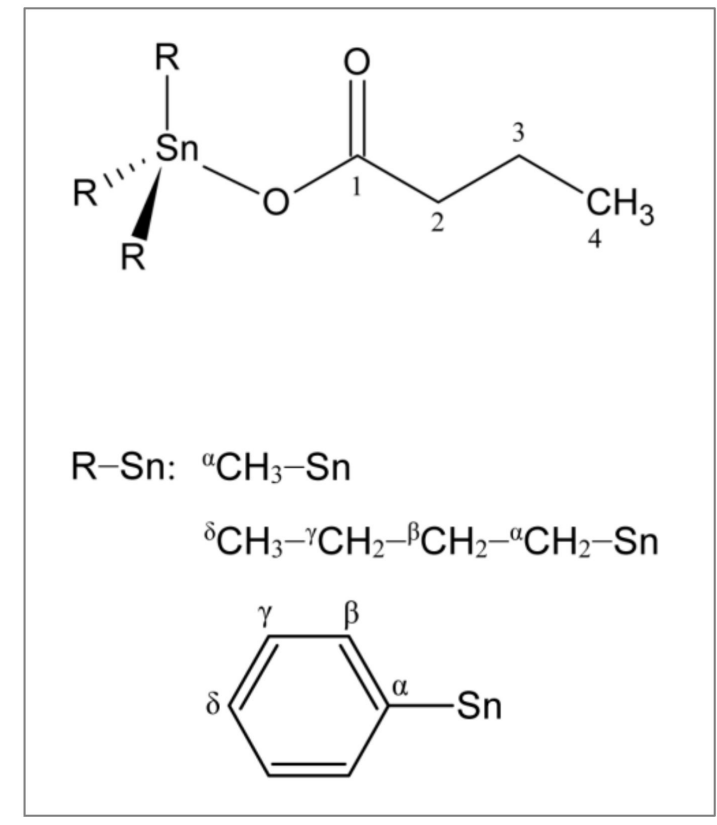

Figure 1. Proposed structure for $\mathrm{R}_{3} \mathrm{Sn}(\mathrm{IV})$ butyrates with the numbering scheme referred to the NMR assignments.

The ${ }^{1} \mathrm{H}$ and ${ }^{13} \mathrm{C}\left\{{ }^{1} \mathrm{H}\right\}$ NMR spectra of the butyric acid and the studied complexes were recorded in $\mathrm{CDCl}_{3}$. Data are given in Materials and Methods (Section 3) and resonances for compounds have been assigned.

The disappearance of the carboxylic proton signal $(\mathrm{OH}$ signal at $\delta 11.85 \mathrm{ppm})$ for all the spectra of the complexes was diagnostic of the coordination of the ligand upon the triorganotin(IV) moieties. For BT1, the measured ${ }^{2} \mathrm{~J}\left({ }^{119} \mathrm{Sn},{ }^{1} \mathrm{H}\right)$ and ${ }^{1} \mathrm{~J}\left({ }^{119} \mathrm{Sn},{ }^{13} \mathrm{C}\right)$ satellites observed in the ${ }^{1} \mathrm{H}$ and ${ }^{13} \mathrm{C}$ spectra, respectively, allowed us to estimate the $\mathrm{C}-\mathrm{Sn}-\mathrm{C}$ angle values of $111^{\circ}[37,38]$. For BT2, only from the ${ }^{2} \mathrm{~J}\left({ }^{119} \mathrm{Sn},{ }^{1} \mathrm{H}\right)$ satellites, it was possible to calculate a C-Sn-C angle of $(113 \pm 2)^{\circ}$ [39]. These values suggest a local tetrahedral Sn geometry, with butyrate binding the $\mathrm{Sn}$ atom conceivably via an ester-like carboxylate. Even in BT3, ${ }^{n} \mathrm{~J}\left({ }^{119} \mathrm{Sn},{ }^{13} \mathrm{C}\right)$ values $(n=1-3)$, together with the values of the $\delta\left({ }^{13} \mathrm{C}\right)$ values of the $\alpha, \beta, \gamma$, and $\delta$ carbon signals, are in agreement with a tetrahedral geometry around the tin center [40].

The ${ }^{119} \mathrm{Sn}\left\{{ }^{1} \mathrm{H}\right\}$ of BT1, BT2, and BT3 showed a single signal at $124.02 \mathrm{ppm}, 100.94 \mathrm{ppm}$ and, $-117.07 \mathrm{ppm}$, respectively, and all the values were typical of four coordinated tin centers, in agreement with what was inferred from the estimated $\mathrm{C}-\mathrm{Sn}-\mathrm{C}$ angle values, the $\delta\left({ }^{13} \mathrm{C}\right)$ values, and the ${ }^{\mathrm{n}} \mathrm{J}\left({ }^{119} \mathrm{Sn},{ }^{13} \mathrm{C}\right)$ values previously discussed. 
The electrospray ionization-mass spectrometry (ESI-MS) spectra of BT1, BT2, and BT3 showed very complicated fragmentation patterns because of the presence of several adducts and a wide range of fragment ions in the first-order mass spectra. Nearly all spectra revealed the peaks relative to the monomeric adducts that BT1, BT2, and BT3 form with $\mathrm{SnMe}_{3}, \mathrm{SnBu}_{3}$, and $\mathrm{SnPh}_{3}$ groups, respectively, and with alkali metal ions such as $\mathrm{Na}^{+}$. Such a complexity is typical of organotin compounds, as previously reported $[41,42]$.

The assignments of the individual ions were based on the combination of positiveion, and tandem mass spectrometric experiments, supported by a comparison between theoretical and experimental isotopic distributions of monomeric. Full positive scans of BT1, BT2, and BT3 spectra are reported in Figure 2a-c, and the isotopic distribution of BT1 is showed in Figure 2d.
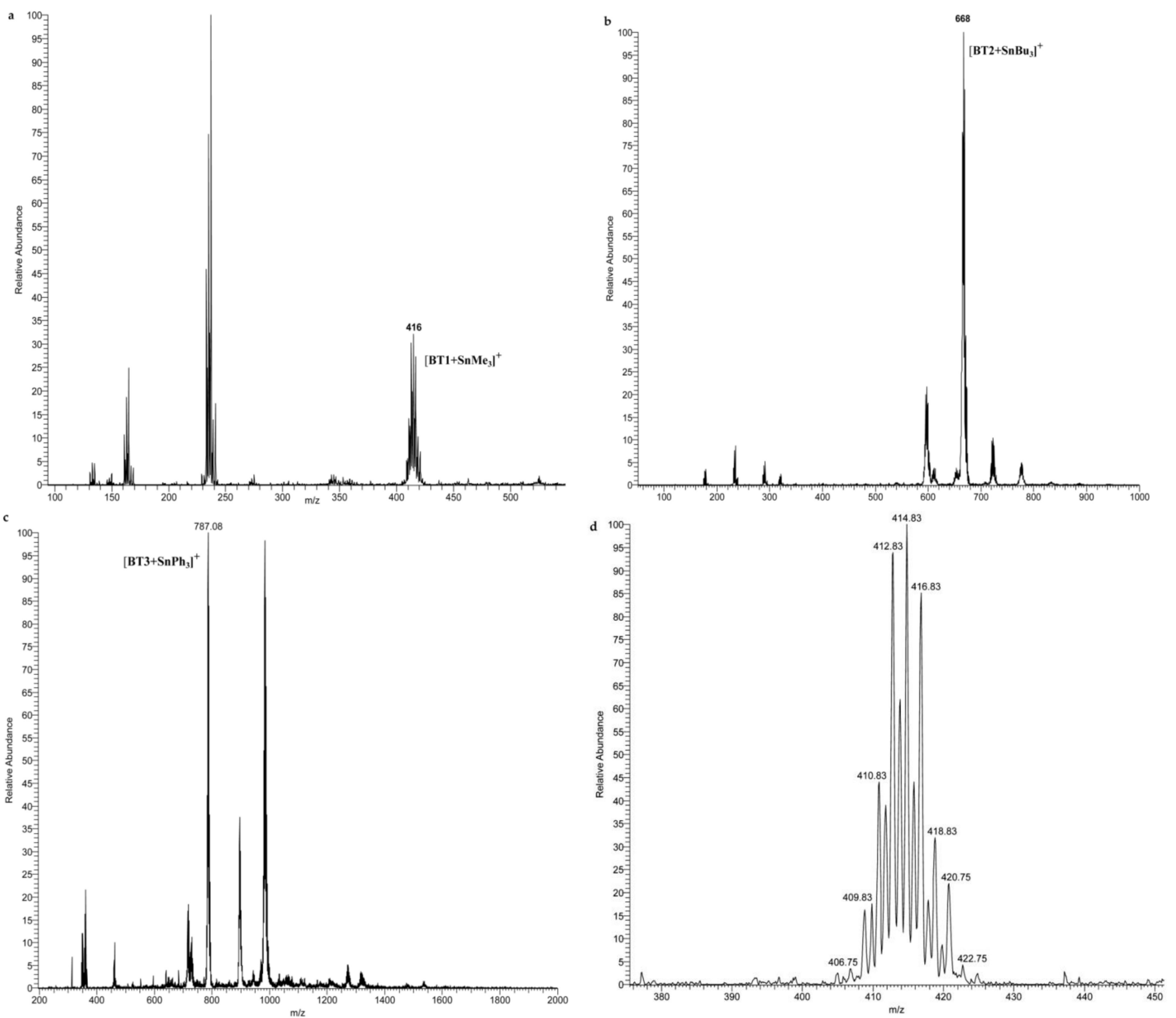

Figure 2. Positive full scan spectra of BT1 (a); BT2 (b); BT3 (c); Compounds and zoom scan spectrum of $m / z 416$ $\left[\mathrm{BT} 1+\mathrm{SnMe}_{3}\right]^{+}(\mathbf{d})$. 


\subsection{Biological Study}

2.2.1. The Effects of Different Triorganotin(IV) Butyrates on Colon Cancer Cells' Viability

As a preliminary screening to test the possible anti-tumor properties of the synthesized compounds, we performed cell viability MTT assay in two colon cancer cell lines, HCT116 and CaCo-2. As Figure 3a shows, tributyltin(IV) butyrate (BT2) presented as the most efficacious among the triorganotin(IV) butyrates analysed, exerting a dose-dependent effect in both cell lines with a maximum effect $(-85 \%$ in HCT116 and $-75 \%$ in CaCo- 2 cells, respectively) observed with $1 \mu \mathrm{M}$ after $48 \mathrm{~h}$ treatment. The parent compound $\mathrm{Bu}_{3} \mathrm{SnCl}$ (TBT) also reduced cell viability but to a lower extent $(-68,9 \%$ in HCT116 and $-45 \%$ in $\mathrm{CaCo}-2)$. On the other hand, neither BT1 nor its parent compound $\mathrm{Me}_{3} \mathrm{SnCl}$ (TMT) were significantly active in the same concentration range, being the maximum effect equal to $-15 \%$ in HCT116 and $-8 \%$ in CaCo-2 cells for BT1. BT3 was not included in the figure because of its poor solubility in solutions compatible with our experimental conditions. Moreover, the parent compound $\mathrm{Ph}_{3} \mathrm{SnCl}$ (TPT) displayed high toxicity, having determined complete cell death even at $0.1 \mu \mathrm{M}$.

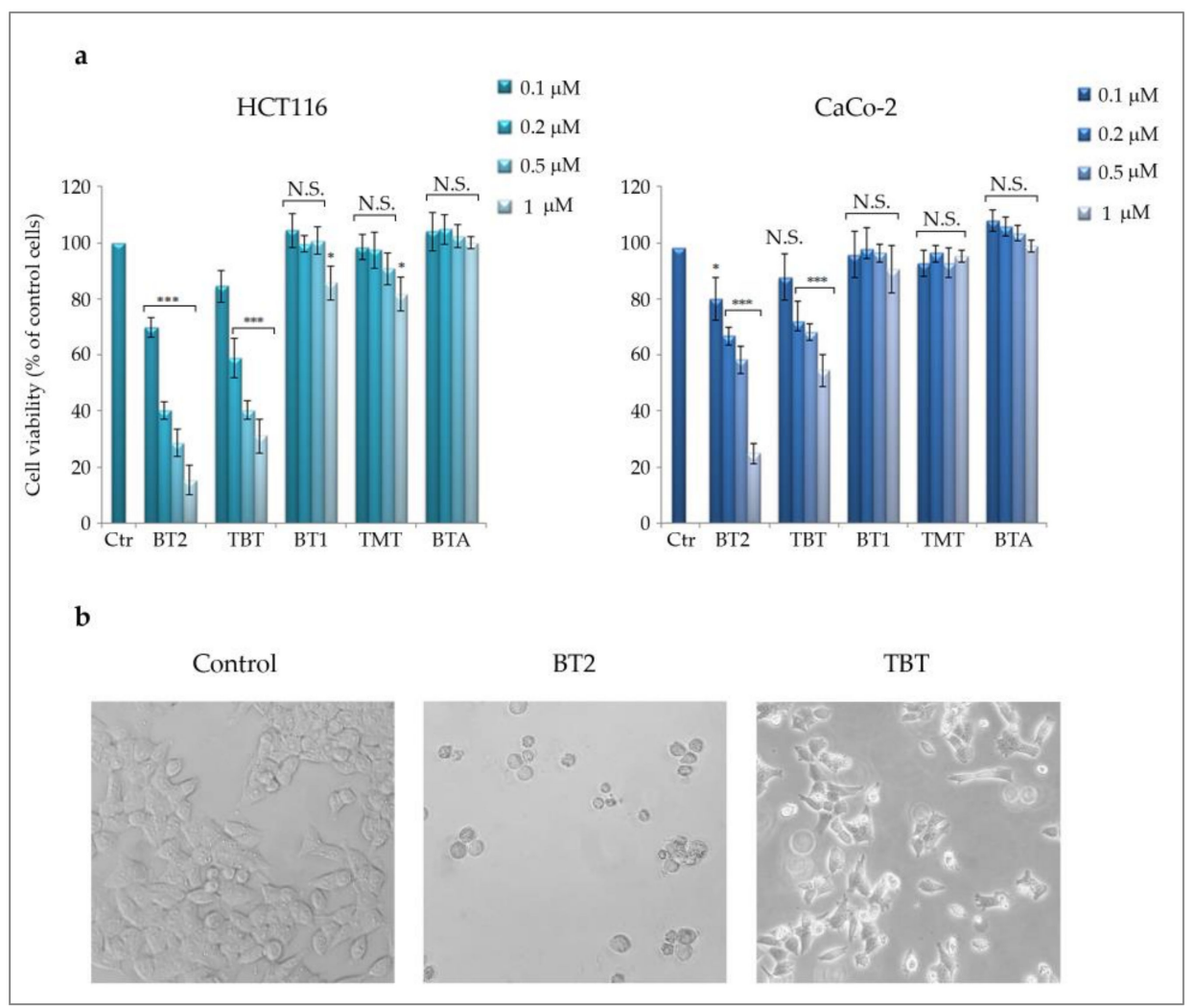

Figure 3. Tributyltin(IV) butyrate (BT2) induces cytotoxic effects in colon cancer cells: (a) MTT assay was used to measure cell viability in two colon cancer cell lines (HCT116 and CaCo-2), as reported in Materials and Methods (Section 3). Cells were incubated for $48 \mathrm{~h}$ in the presence of the conjugates (BT2 and BT1) and the corresponding parent compounds (TBT and TMT) at the indicated concentrations. The effects of butyric acid (BTA) were also evaluated. The results reported in the histograms are representative of three separate experiments: $\left({ }^{*}\right) p$-value $<0.05 ;\left({ }^{* * *}\right) p$-value $<0.001$ compared with untreated cells; N.S. = not significant; (b) Morphological analysis of HCT116 cells treated with $0.5 \mu \mathrm{M}$ BT2 and TBT for $48 \mathrm{~h}$. The cells were visualized under a light microscope at $200 \times$ magnification and the pictures were acquired by IM50 Leica Software (Leika Microsystems, Wetzlar, Germany).

It is interesting to note that the butyrate was not capable of determining any effect on cell viability at any concentration used, but data not shown, and in accordance with other observations, indicated that it is active in the range of $1-5 \mathrm{mM}$ in colon cancer cells [43]. 
Considering these results, we focused the attention on BT2 and we chose HCT116 cells as the most susceptible cell line. Morphological analysis specifically performed in these cells showed that BT2 caused typical features of cell death; cells appeared round shaped and detached from the substrate. Interestingly, the parent compound TBT reduced the cell number, an event that can be considered as in accordance with MTT data, but the cells appeared viable, thus suggesting an anti-proliferative effect (Figure $3 b$ ). As for this evaluation, in all subsequent experiments a $0.5 \mu \mathrm{M}$ concentration was chosen to compare the effects of BT2 and TBT.

\subsubsection{The Effect of BT2 on Cell Cycle and ER Stress}

To investigate the difference between the effects of BT2 and its parent TBT, we analysed the cell cycle distribution profiles. Data reported in Figure 4a shows that BT2 induced a marked increase in the pre-G0/G1 peak (21.1\% compared to $6.9 \%$ in the control), indicating DNA fragmentation that can be associated with cell death. In addition, a slight increase in the G2/M phase was observed in this condition (from $24.4 \%$ in the control to 28.7 with BT2), suggesting a possible shift to cell death following cell cycle arrest in this phase. Concerning the parental compound TBT, G2/M phase arrest was predominant $(50.1 \%)$, whereas DNA pre-G0/G1 was quite modest (7.9\%). Such a result is in line with the anti-proliferative effect of TBT, which was not accompanied with cell death. Biochemically, it is interesting to observe that only TBT induced a marked increase in the cyclin-dependent kinase (CDK) inhibitor p21 and a concomitant decrease in the levels of cyclin B1 (Figure 4b). Both sets of data nicely correlate with G2/M arrest, as previously described by Lallemand et al. [44]. In contrast, BT2 only slightly modified p21 and cyclin B1 levels, a result that can be interpreted considering the slight increase in $\mathrm{G} 2 / \mathrm{M}$ phase and the predominance of cell death induced by the compound.

Evidence has been provided that G2/M arrest can correlate with ER stress and possibly with subsequent apoptosis [45]. Therefore, we analysed some important ER stress markers, such as the $78 \mathrm{kDa}$ glucose-regulated protein (Grp78), the initiator of the unfolded protein response (UPR), RNA-dependent protein kinase (PKR)-like ER kinase (PERK), its target eukaryotic initiation factor 2 (eIF2 $\alpha$ ) in the phosphorylated form, and the downstream transcription factor C/EBP homologous protein (CHOP). The levels of Grp78 and PERK markedly increased following treatment with BT2 or TBT (Figure 4c), indicating that ER stress occurs in both conditions, most likely correlating with the organotin moiety. However, increase in the levels of phosphorylated IF $2 \alpha$ and CHOP was only observed following the BT2 treatment. It is thus possible to deduce that UPR was effectively triggered following BT2 treatment and not TBT, an observation which is in line with the ability of BT2 to promote cell death. This conclusion is also supported by the evidence that $\mathrm{CHOP}$ represents a key transcription factor that correlates persistent ER stress with the induction of apoptosis.

In order to characterise BT2-induced cell death and verify apoptosis induction, we made further biochemical evaluations. 


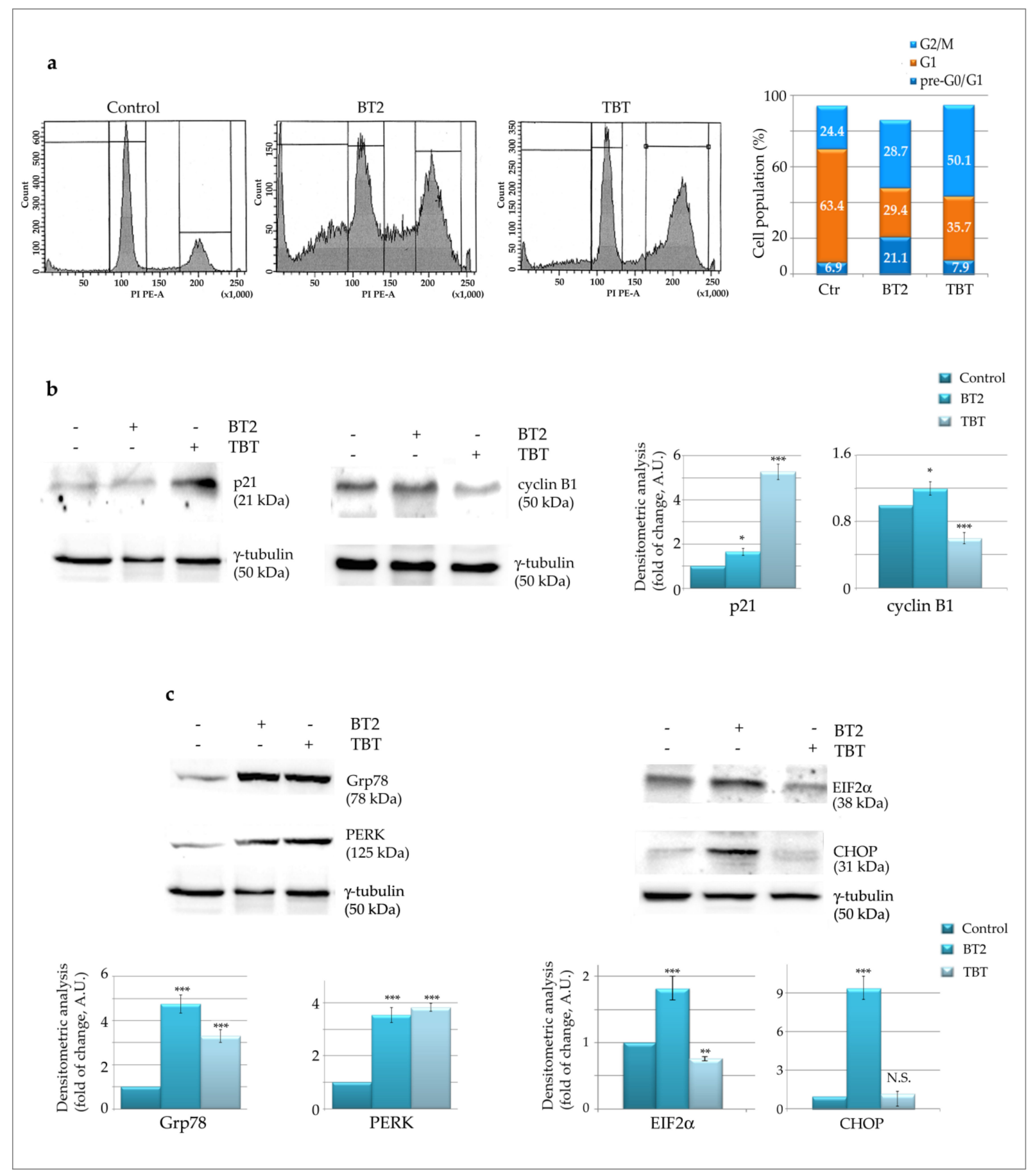

Figure 4. Tributyltin(IV) butyrate (BT2) induces cell cycle arrest accompanied by ER stress induction and DNA fragmentation: (a) The cell cycle phase distribution of HCT116 cells was evaluated by flow cytometry analysis. Cells were incubated for $48 \mathrm{~h}$ in the presence of $0.5 \mu \mathrm{M}$ BT2 or TBT. Then, the DNA content was evaluated after incubating the cells in a hypotonic propidium iodide solution, as described in Section 3. Fluorescence was estimated by FacsDiva Software. (b,c) Western blot analysis of p21 and cyclin B1, two proteins differently expressed during the cell cycle phases (b), and Grp78, PERK, Phospho eIF2 $\alpha$, and CHOP markers of endoplasmic reticulum stress (c). Cells were incubated for $48 \mathrm{~h}$ in the presence of $0.5 \mu \mathrm{M}$ BT2 or TBT. The correct protein loading was ascertained by evaluating $\gamma$-tubulin levels. Representative blots of three independent experiments and densitometric analysis are shown. $\left({ }^{*}\right) p$-value $<0.05 ;\left({ }^{* *}\right) p$-value $<0.01 ;\left({ }^{* * *}\right) p$-value $<0.001$ compared with untreated cells. N.S. = not significant. 


\subsubsection{BT2 Promotes Apoptotic Cell Death}

In order to confirm the morphological data suggesting that BT2 induces cell death, we stained the cells with Hoechst, a vital dye that highlights the nuclei. As shown in Figure 5a, BT2 treatment produced a marked effect of chromatin condensation and fragmentation, evidenced as bright spots, whereas TBT only reduced the cell number compared to the control, with the nuclei appearing still intact. Moreover, investigating apoptotic markers by Western blot analysis revealed that BT2 was capable of reducing the levels of pro-caspase-9 and pro-caspase-3, an indication of their activation (Figure $5 b$ ). These effects were less evident with TBT. We also focused on poly-ADP ribose polymerase (PARP), a well-known caspase-3 substrate. A significant reduction in PARP level was observed following BT2 treatment and this effect was not obtained with TBT. However, in this condition PARP cleavage fragments were not detected, suggesting that complete PARP degradation possibly occurred. We cannot exclude the intervention of other proteases in PARP degradation, in accordance with the observations of Chaitanya et al. [46].

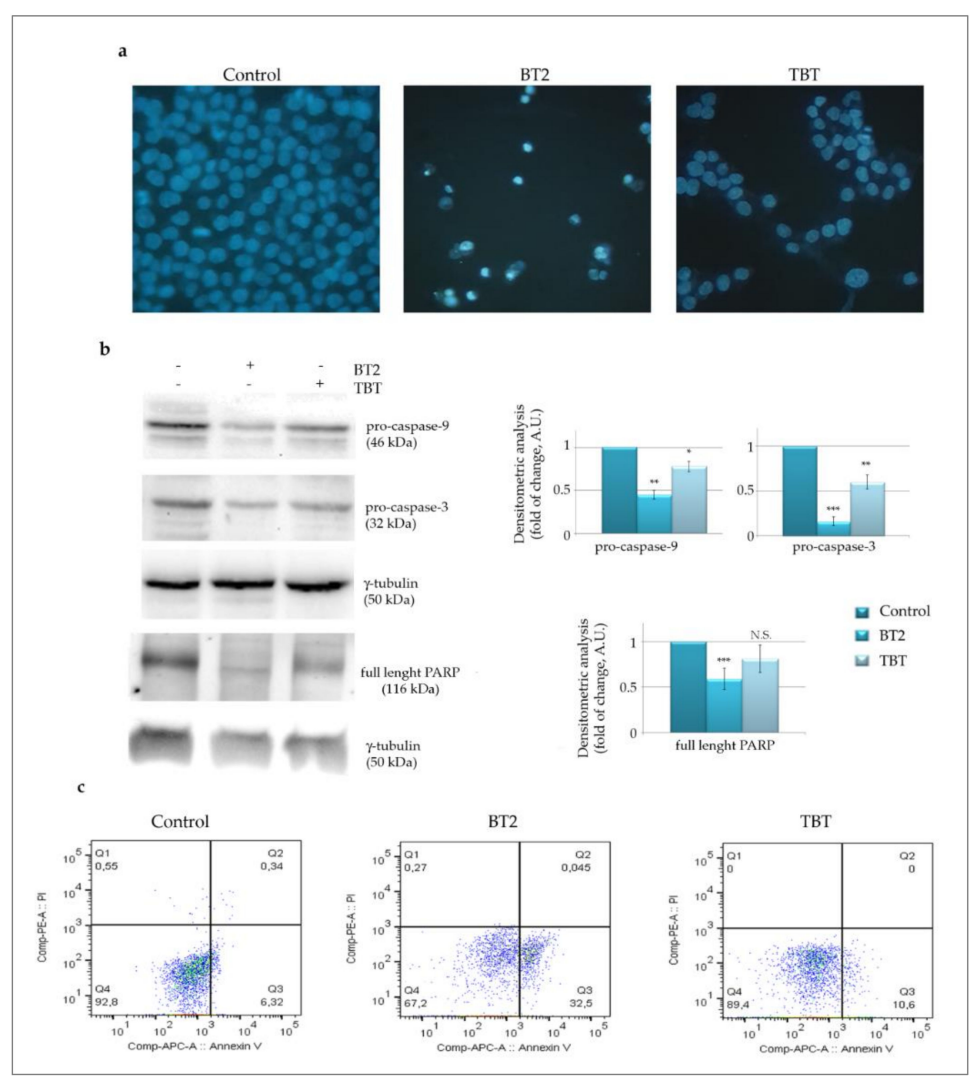

Figure 5. Tributyltin(IV) butyrate (BT2) activates caspase-dependent apoptotic cell death pathway. (a) Cells were incubated for $48 \mathrm{~h}$ in the presence of $0.5 \mu \mathrm{M}$ BT2 or TBT. At the end of incubation, cells were stained with the vital dye Hoechst 333428 that permits to visualize nuclei. Cells were then visualised under fluorescence microscope Leika equipped with a DAPI filter (magnification of $\times 400$ ). Micrographs are representative of almost two fields from two independent experiments; (b) Western blot analysis of apoptotic markers, pro-caspase-9, pro-caspase-3 and PARP, in cells treated as in (a). The correct protein loading was ascertained by evaluating $\gamma$-tubulin levels. Representative blots of three independent experiments and densitometric analysis are shown; (c) AnnexinV positivity confirmed early apoptosis. Cells were treated with the compounds for $24 \mathrm{~h}$ and subjected to Annexin $\mathrm{V}$ apoptosis detection kit as reported in Materials and methods. Analysis was performed by flow cytometry using FacsCanto BD. The percentage of annexin V positive cells was evaluated by Flowjo BD software. The results are representative of two independent experiments $\left.{ }^{*}\right) p$-value $<0.05$; $\left.{ }^{* *}\right) p$-value $\left.<0.01 ;{ }^{* * *}\right) p$-value $<0.001$ compared with untreated cells. N.S. not significant. 
To further confirm apoptosis induction, we stained the cells with annexinV, an early apoptotic indicator that detects the exposure of phosphatidylserine to the outer side of the plasma membrane, an event which is associated with classic apoptosis commitment.

The results shown in Figure $5 \mathrm{c}$ indicate that only BT2 significantly increased the percentage of annexin $\mathrm{V}$ positive cells at $24 \mathrm{~h}$ treatment (32.5\% compared to the control $6.32 \%$ ).

Interestingly, the parental compound TBT did not significantly increase annexin V positivity (only $10.6 \%$ ), thus confirming that apoptosis is specifically triggered by BT2 only.

\subsubsection{BT2 Induces Histone Deacetylation}

It is well known that butyrate behaves as an epigenetic compound since at $\mathrm{mM}$ concentration range it is capable of inhibiting HDACs with consequent histone hyperacetylation $[17,47]$. Moreover, evidence has been provided that butyrate, at low concentrations, activates histone acetyl transferases (HATs), being metabolized to acetyl-CoA, which is important not only as an energy source but also as HATs substrate [47].

In order to investigate whether BT2 also exerts an epigenetic effect, we first evaluated histone acetylation pattern in comparison with butyric acid. To this purpose, we analysed acetyl-H3 and acetyl-H4 histones, two major substrates of both HATs and HDACs.

Surprisingly, the results shown in Figure 6a clearly indicate that BT2 dramatically reduces histone acetylation, an effect that was also observed with the parental compound TBT. On the other hand, butyric acid, at the same concentration $(0.5 \mu \mathrm{M})$, was not capable of exerting any significant effect whereas at $5 \mathrm{mM}$ produced the typical remarkable increase in both acetyl-H3 and acetyl-H4 histones (Figure 6b). It is noteworthy that the level of total $\mathrm{H} 3$ and $\mathrm{H} 4$ histones, considered as loading controls, was just slightly reduced by the treatment with the compounds. Densitometric analysis performed considering the ratio between acetylated/total histones confirmed that the acetylated forms markedly decreased.

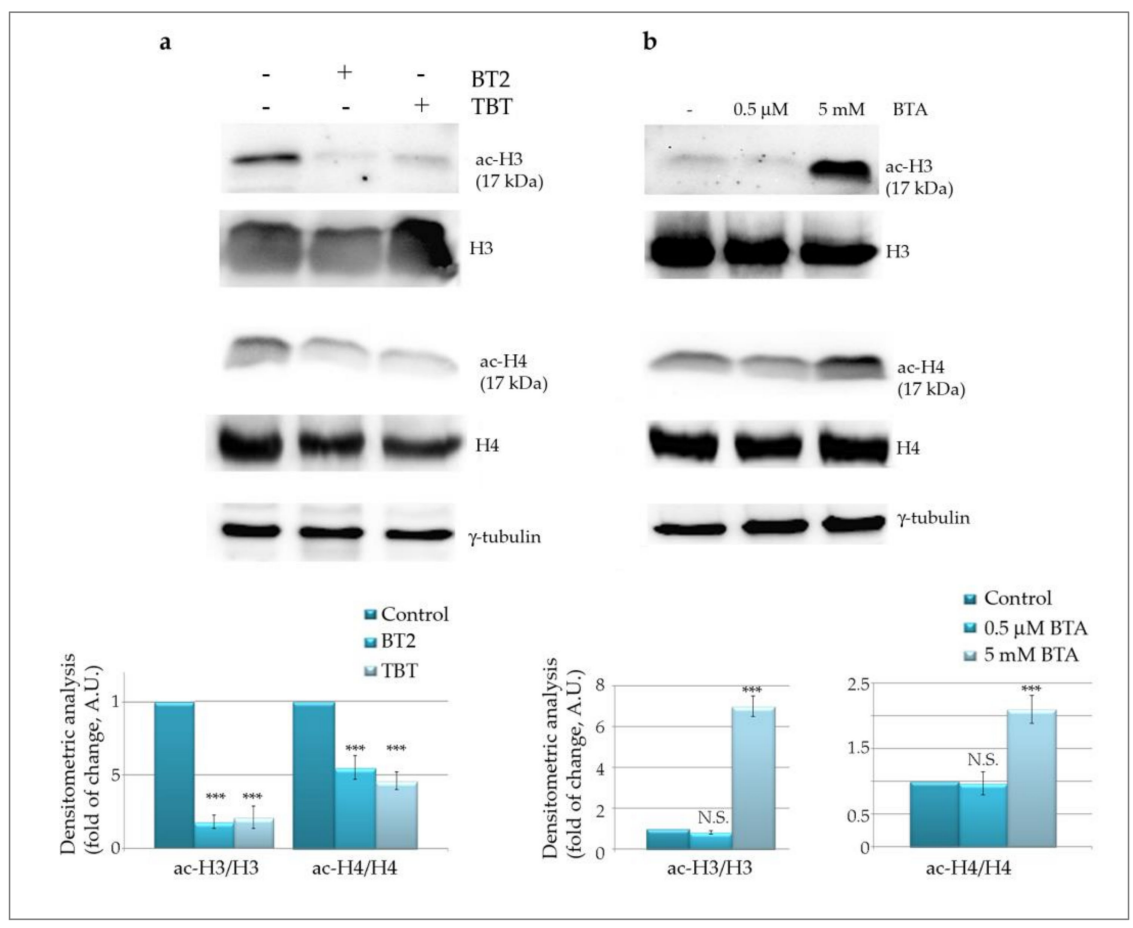

Figure 6. Tributyltin(IV) butyrate (BT2) remarkably reduces histone acetylation. Western blot analysis of acetylated-H3 and $\mathrm{H} 4$ histones after treatment for $48 \mathrm{~h}$ with $0.5 \mu \mathrm{M}$ BT2 and TBT (a) or $0.5 \mu \mathrm{M}$ and $5 \mathrm{mM}$ butyric acid (BTA) (b) are shown. The ratio between acetylated histones and total histone levels was quantified. Representative blots of three independent experiments and densitometric analysis are shown. $\left.{ }^{* * *}\right) p$-value $<0.001$ compared with untreated cells. N.S. $=$ not significant. 
Since histone deacetylation was obtained with both BT2 and TBT, these data may be interpreted as a specific effect of the tributyltin moiety. If this hypothesis is correct, it is possible to assume that the BT2 compound does not maintain the deacetylation inhibiting activity of its ligand butyrate.

In order to verify whether BT2 produces histone deacetylation by activating HDACs, we performed experiments in the presence of suberoylanilide hydroxamic acid (SAHA), another potent HDAC inhibitor [48].

To see whether BT2 could specifically prevent SAHA-induced histone acetylation, we pre-treated the cells for $24 \mathrm{~h}$ with BT2 and added SAHA for the successive $24 \mathrm{~h}$. Data reported in Figure 7 confirms that BT2 alone markedly reduces the levels of both acetyl $\mathrm{H} 3$ and acetyl H4. Conversely, SAHA alone produced a remarkable increase in histone acetylation. Interestingly, pre-treatment with BT2 was capable of counteracting SAHAmediated deacetylation of both histones. Considering the well-known HDAC inhibitory action of SAHA, these data strongly suggest that BT2 may act as an HDAC activator.

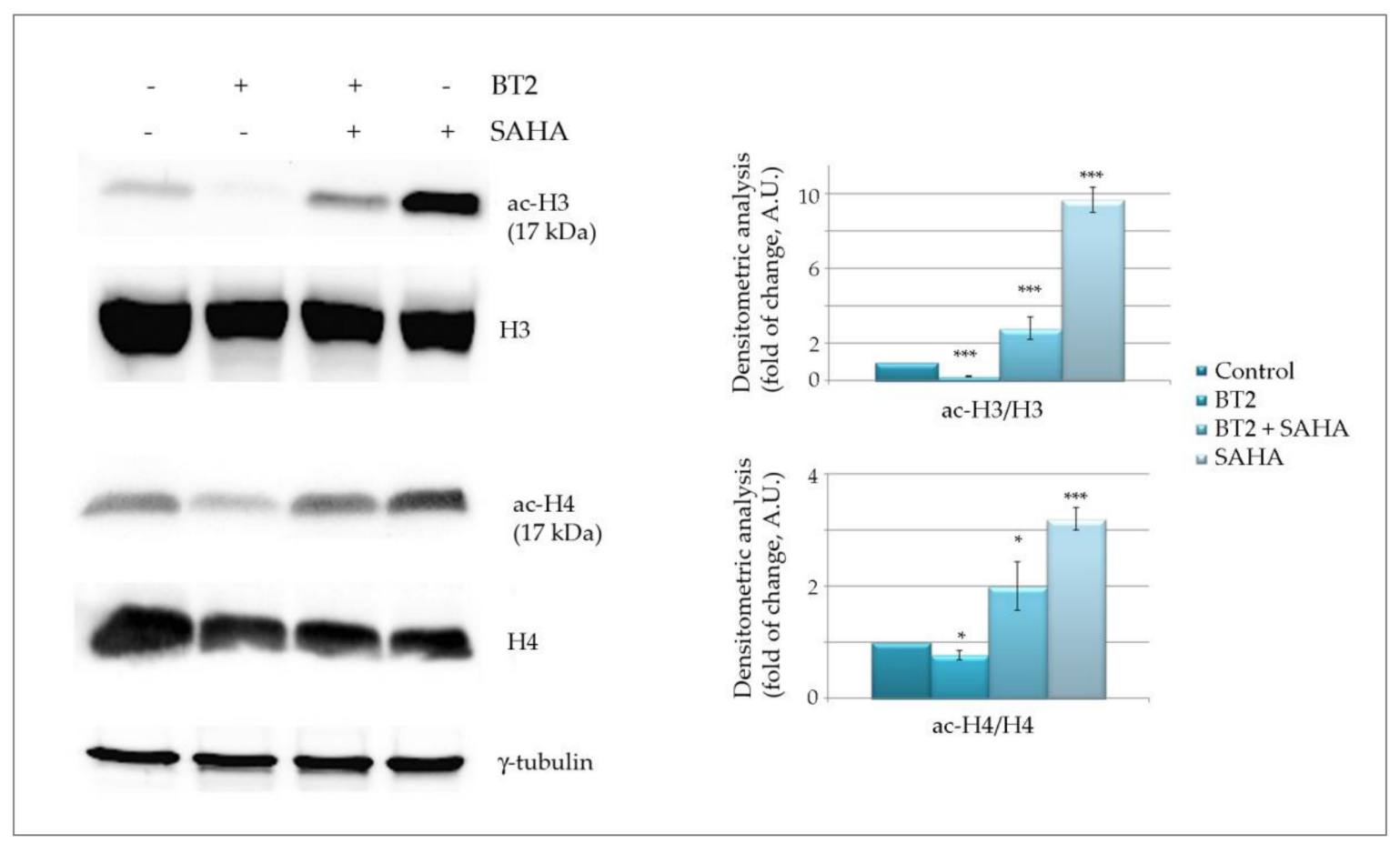

Figure 7. Tributyltin(IV) butyrate (BT2) reduces the effect of the HDAC inhibitor SAHA on histone acetylation. The figure shows Western blot analysis of acetylated-H3 and $\mathrm{H} 4$ histones after cell treatment for $48 \mathrm{~h}$ with $0.5 \mu \mathrm{M}$ BT2 (lane 2) or $24 \mathrm{~h}$ treatment with $10 \mu \mathrm{M}$ SAHA used alone (lane 4$)$ or after pre-treatment with BT2 $(24 \mathrm{~h})$ followed by other $24 \mathrm{~h}$ of incubation with the HDAC inhibitor (lane 3). The ratio between acetylated histones and total histone levels was quantified. Representative blots of three independent experiments and densitometric analysis are shown. $\left({ }^{*}\right) p$-value $<0.05$; $\left.{ }^{* * *}\right) p$-value $<0.001$ compared with untreated cells. N.S. $=$ not significant.

Further study specifically focusing on epigenetic profile of BT2 action will verify this hypothesis and better characterise the effects of the tributyltin moiety.

\section{Materials and Methods}

\subsection{Materials}

Reagents $\mathrm{Me}_{3} \mathrm{SnOH},\left(\mathrm{Bu}_{3} \mathrm{Sn}\right)_{2} \mathrm{O}, \mathrm{Ph}_{3} \mathrm{SnOH}$, and $\mathrm{BTA}$ used in the experiment were purchased at commercial analytical grade from commercial sources (Sigma-Aldrich, St. Louis, Missouri, USA) and used directly without further purification. 


\subsection{Synthetic Procedures of Triorganotin(IV) Complexes}

Triorganotin(IV) complexes of butyric acid (BTA) were obtained by the same method: BTA $(0.356 \mathrm{~g}, 4 \mathrm{mmol})$ was added to a methanol solution $(200 \mathrm{~mL})$ with the stoichiometric amount for the corresponding triorganotin oxide or hydroxide $\left(\mathrm{Me}_{3} \mathrm{SnOH}: 0.7228 \mathrm{~g}, 4 \mathrm{mmol}\right.$; $\left(\mathrm{Bu}_{3} \mathrm{Sn}\right)_{2} \mathrm{O}: 1.2420 \mathrm{~g}, 2 \mathrm{mmol} ; \mathrm{Ph}_{3} \mathrm{SnOH}: 1.4681 \mathrm{~g}$, $4 \mathrm{mmol}$, respectively, for compounds BT1, $\mathrm{BT} 2$, and BT3). The mixtures were kept refluxing overnight. White solids were recovered upon cooling after concentration in a rotary evaporator. After filtration and vacuum drying, the solids were recrystallized from petroleum ether and analyzed.

\subsubsection{Trimethyltin(IV) butyrate (BT1)}

Physical state: white solid; yield: $82 \%$. m.p. $124-126^{\circ} \mathrm{C}$. Formula Weight, $\mathrm{FW}=250.91$. Anal. Calc. for $\mathrm{C}_{7} \mathrm{H}_{16} \mathrm{O}_{2} \mathrm{Sn}$ : C 33.51; H 6.43; Sn 47.31\%; Found: C 33.74; H 6.47; Sn 47.27\%. IR $\left(\mathrm{KBr}, \mathrm{cm}^{-1}\right): 1565 v_{\text {as }}\left(\mathrm{COO}^{-}\right), 1345 v_{\mathrm{s}}\left(\mathrm{COO}^{-}\right), 545(\mathrm{Sn}-\mathrm{C}), 488(\mathrm{Sn}-\mathrm{O}), 220 \Delta v .{ }^{1} \mathrm{H}$ $\mathrm{NMR}\left(\mathrm{CDCl}_{3}, \mathrm{ppm}\right): 2.24\left(\mathrm{t}, 2 \mathrm{H}, \mathrm{CH}_{2}\right.$ (2) ligand); 1.60 (m, 2H, $\mathrm{CH}_{2}(3)$ ligand); 0.90 (t, $3 \mathrm{H}$, $\mathrm{CH}_{3}(4)$ ligand); 0.51 (s, 9H, $\left.\mathrm{CH}_{3}-\alpha ;{ }^{2} \mathrm{~J}\left({ }^{119} \mathrm{Sn}-{ }^{1} \mathrm{H}\right)=58 \mathrm{~Hz}\right) .{ }^{13} \mathrm{C} \mathrm{NMR}\left(\mathrm{CDCl}_{3}, \mathrm{ppm}\right): 181.23$ $(\mathrm{COOH}) ; 39.57$ (C2 ligand); 21.53 (C3 ligand); 16.58 (C4 ligand); $0.09\left(\mathrm{CH}_{3}-\alpha,{ }^{1} \mathrm{~J}\left({ }^{119} \mathrm{Sn}-{ }^{13} \mathrm{C}\right)\right.$, $400 \mathrm{~Hz}) .{ }^{119} \mathrm{Sn}$ NMR (ppm): 124.02. ESI-MS: $m / z 416\left[\mathrm{BT} 1+\mathrm{SnMe}_{3}\right]^{+} ; m / z 274[\mathrm{BT} 1+\mathrm{Na}]^{+}$; $m / z 236\left[\mathrm{BT} 1-\mathrm{CH}_{3}\right]^{+} ; m / z 165\left[\mathrm{SnMe}_{3}\right]^{+}$. MS $/ \mathrm{MS}$ of $m / z$ 237: $m / z 206\left[\mathrm{BT}^{-}-3 \mathrm{CH}_{3}\right]^{+} ; m / z$ $165\left[\mathrm{SnMe}_{3}\right]^{+} ; m / z 150\left[\mathrm{SnMe}_{2}\right]^{+}$. MS/MS of $m / z$ 237: $m / z 150\left[\mathrm{SnMe}_{2}\right]^{+}$.

\subsubsection{Tributyltin(IV) butyrate (BT2)}

Physical state: white solid; yield: $85 \%$. m.p. $68-69^{\circ} \mathrm{C}$. Formula Weight, $\mathrm{FW}=377.15$. Anal. Calc. for $\mathrm{C}_{16} \mathrm{H}_{34} \mathrm{O}_{2} \mathrm{Sn}$ : C 50.95; H 9.09; Sn 31.48\%; Found: C 51.21; H 9.12; Sn 31.27\%. IR $\left(\mathrm{KBr}, \mathrm{cm}^{-1}\right): 1574 v_{\text {as }}\left(\mathrm{COO}^{-}\right), 1338 v_{\mathrm{s}}\left(\mathrm{COO}^{-}\right), 508(\mathrm{Sn}-\mathrm{C}), 488(\mathrm{Sn}-\mathrm{O}), 236 \Delta v .{ }^{1} \mathrm{H}$ $\operatorname{NMR}\left(\mathrm{CDCl}_{3}, \mathrm{ppm}\right): 2.26\left(\mathrm{t}, 2 \mathrm{H}, \mathrm{CH}_{2}\right.$ (2) ligand); $1.60\left(\mathrm{~m}, 8 \mathrm{H}, 2 \times \mathrm{CH}_{2}(3)\right.$ ligand and $6 \times$ $\left.\mathrm{CH}_{2}-\alpha ;{ }^{2} \mathrm{~J}\left({ }^{119} \mathrm{Sn}-{ }^{1} \mathrm{H}\right)=70 \mathrm{~Hz}\right) ; 1.31\left(\mathrm{~m}, 6 \mathrm{H}, \mathrm{CH}_{2}-\beta\right) ; 1.23\left(\mathrm{~m}, 6 \mathrm{H}, \mathrm{CH}_{2}-\gamma\right) ; 0.89(\mathrm{t}, 12 \mathrm{H}$, $3 \times \mathrm{CH}_{3}(4)$ ligand and $\left.9 \mathrm{CH}_{3}-\delta\right) .{ }^{13} \mathrm{C} \mathrm{NMR}\left(\mathrm{CDCl}_{3}, \mathrm{ppm}\right): 181.85(\mathrm{COOH}) ; 39.28(\mathrm{C} 2$ ligand); 30.43 (C- $\beta$ ); 29.57 (C- $\gamma$ ); 21.84 (C3 ligand); 18.99 (C- $\alpha$ ); 16.26 (C4 ligand); $\mathrm{C}-\delta$ not observed. ${ }^{119} \mathrm{Sn}$ NMR (ppm): 100.94. ESI-MS: $m / z 777[2 \mathrm{BT} 2+\mathrm{Na}]^{+} ; m / z 720$ [2BT2butyl $+\mathrm{Na}]^{+} ; \mathrm{m} / \mathrm{z} 668\left[\mathrm{BT} 2+\mathrm{SnBu}_{3}\right]^{+} ; m / z 600[2 \mathrm{BT} 2-\mathrm{SnBu}+\mathrm{Na}]^{+} ; m / z 320\left[\mathrm{BT} 2-\right.$ butyl] ${ }^{+} ; \mathrm{m} / z$ $291\left[\mathrm{SnBu}_{3}\right]^{+} ; m / z 234\left[\mathrm{SnBu}_{2}\right]^{+} ; m / z 177[\mathrm{SnBu}]^{+}$. MS/MS of $m / z$ 777: $m / z 400[\mathrm{BT} 2+\mathrm{Na}]^{+}$; $m / z 291\left[\mathrm{SnBu}_{3}\right]^{+}$. MS/MS of $m / z$ 720: $m / z 378$ [BT2+H] ${ }^{+} ; m / z 320$ [BT2-butyl] ${ }^{+}$. MS/MS

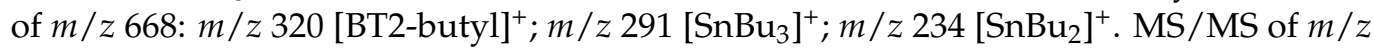
600: $m / z 291\left[\mathrm{SnBu}_{3}\right]^{+} ; m / z 234\left[\mathrm{SnBu}_{2}\right]^{+}$.

\subsubsection{Triphenyltin(IV) butyrate (BT3)}

Physical state: white solid; yield: $84 \%$. Decomposition temperature: $218-220{ }^{\circ} \mathrm{C}$. Formula Weight, FW: 437.12. Anal. Calc. for $\mathrm{C}_{22} \mathrm{H}_{22} \mathrm{O}_{2} \mathrm{Sn}$ : C 60.45; H 5.07; Sn 27.16\%; Found: C 60.28; H 4.96; Sn 27.43\%. IR (KBr, cm $\left.{ }^{-1}\right): 1573 v_{\text {as }}\left(\mathrm{COO}^{-}\right), 1342 v_{\mathrm{s}}\left(\mathrm{COO}^{-}\right)$, 495 (Sn-O), 454 (Whiffen Y-mode [36]), $231 \Delta v .{ }^{1} \mathrm{H} \mathrm{NMR}\left(\mathrm{CDCl}_{3}, \mathrm{ppm}\right): 7.73(\mathrm{~m}, 6 \mathrm{H}$, $\mathrm{H}-\beta$ aromatic, $\left.{ }^{3} \mathrm{~J}\left({ }^{119} \mathrm{Sn}-{ }^{1} \mathrm{H}\right), 54.0 \mathrm{~Hz}\right) ; 7.44(\mathrm{~m}, 9 \mathrm{H}, 6 \times \mathrm{H}-\gamma, 3 \times \mathrm{H}-\delta$ aromatic $) ; 2.40$ (t, $2 \mathrm{H}, \mathrm{CH}_{2}(2)$ ligand); $1.68\left(\mathrm{~m}, 2 \mathrm{H}, \mathrm{CH}_{2}(3)\right.$ ligand); $0.92\left(\mathrm{t}, 3 \mathrm{H}, \mathrm{CH}_{3}(4)\right.$ ligand). ${ }^{13} \mathrm{C}$ $\operatorname{NMR}\left(\mathrm{CDCl}_{3}, \mathrm{ppm}\right): 181.54(\mathrm{COOH}) ; 141.06\left(\mathrm{C}-\alpha\right.$ aromatic, $\left.{ }^{1} \mathrm{~J}\left({ }^{119} \mathrm{Sn}-{ }^{13} \mathrm{C}\right)=652.4 \mathrm{~Hz}\right)$; $139.79\left(\mathrm{C}-\beta\right.$ aromatic, $\left.{ }^{2} \mathrm{~J}\left({ }^{119} \mathrm{Sn}-{ }^{13} \mathrm{C}\right)=47.5 \mathrm{~Hz}\right) ; 132.66$ (C- $\delta$ aromatic); $131.46(\mathrm{C}-\gamma$ aromatic, $\left.{ }^{3} \mathrm{~J}\left({ }^{119} \mathrm{Sn}-{ }^{13} \mathrm{C}\right)=64.4 \mathrm{~Hz}\right) ; 38.62$ (C2 ligand); 21.80 (C3 ligand); 16.39 (C4 ligand). ${ }^{119} \mathrm{Sn}$ NMR

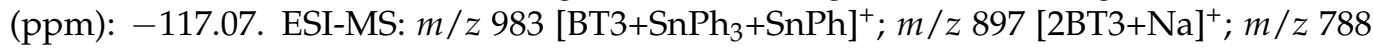
$\left[\mathrm{BT} 3+\mathrm{SnPh}_{3}\right]^{+} ; m / z 719\left[\left(\mathrm{SnPh}_{3}\right)_{2} \mathrm{O}+\mathrm{H}\right]^{+} ; m / z 460[\mathrm{BT} 3+\mathrm{Na}]^{+} ; m / z 360$ [BT3-benzene] $m / z 351\left[\mathrm{SnPh}_{3}\right]^{+}$. MS/MS of $m / z$ 788: $m / z 360$ [BT3-benzene] ${ }^{+}$; MS/MS of $m / z$ 719: $m / z$ $642\left[\left(\mathrm{SnPh}_{3}\right)_{2} \mathrm{O} \text {-benzene }\right]^{+} ; m / z 351\left[\mathrm{SnPh}_{3}\right]^{+}$. MS $/ \mathrm{MS}$ of $m / z$ 351: $m / z 195[\mathrm{SnPh}]^{+}$.

\subsection{Instrumentation}

All melting points were measured on a Stuart SMP3 melting point apparatus Bibby Scientific Ltd., Stone, UK. 
The IR spectra were recorded in wavenumber $\left(v, \mathrm{~cm}^{-1}\right)$ as nujol and hexachlorobutadiene mulls on a Frontier Spectrophotometer PerkinElmer FTIR (Milan, Italy) between CsI windows in the $4000-250 \mathrm{~cm}^{-1}$ region and in potassium bromide $(\mathrm{KBr})$ disks in the range $4000-400 \mathrm{~cm}^{-1}$.

${ }^{1} \mathrm{H},{ }^{13} \mathrm{C}\left\{{ }^{1} \mathrm{H}\right\}$ NMR spectra were recorded on a Bruker ARX 300 (7.04 T) spectrometer (Rheinstetten, Germany), at $300 \mathrm{~K}$. One-dimensional ${ }^{1} \mathrm{H},{ }^{13} \mathrm{C}\left\{{ }^{1} \mathrm{H}\right\}$ spectra in deuterated chloroform $\left(\mathrm{CDCl}_{3}\right)$ solution were acquired at 400.15 and $100.61 \mathrm{MHz}$, with a SW of $10 \mathrm{ppm}$ and 200 ppm for ${ }^{1} \mathrm{H}$ and ${ }^{13} \mathrm{C}\left\{{ }^{1} \mathrm{H}\right\}$, respectively. ${ }^{1} \mathrm{H}$ and ${ }^{13} \mathrm{C}$ resonances were calibrated on the corresponding solvent signals, ${ }^{1} \mathrm{H}, \delta=7.27 \mathrm{ppm} ;{ }^{13} \mathrm{C}, \delta=77.32 \mathrm{ppm}$ with respect to the $\mathrm{Me}_{4} \mathrm{Si}$ (TMS) [49].

Solution ${ }^{119} \mathrm{Sn}\left\{{ }^{1} \mathrm{H}\right\}$ NMR data were recorded on Bruker Avance II $400 \mathrm{MHz}(9.40 \mathrm{~T})$ spectrometer (Bruker BioSpin $\mathrm{GmbH}$, Rheinstetten, Germany) at $300 \mathrm{~K}$, in $\mathrm{CDCl}_{3}$. Onedimensional ${ }^{119} \mathrm{Sn}\left\{{ }^{1} \mathrm{H}\right\}$ spectra were acquired at $149.21 \mathrm{MHz}$ with a spectral width (SW) of 800 ppm by investigating four spectral windows with SW $=250 \mathrm{ppm}$ at once in the +200 :-600 ppm range. For ${ }^{119} \mathrm{Sn}, \mathrm{Me}_{4} \mathrm{Sn}$ was used as external reference $\left({ }^{119} \mathrm{Sn} \delta=0.00 \mathrm{ppm}\right)$

${ }^{119} \mathrm{Sn}\left\{{ }^{1} \mathrm{H}\right\}$ and ${ }^{13} \mathrm{C}\left\{{ }^{1} \mathrm{H}\right\}$ spectra were acquired with broadband proton power-gated decoupling. For all nuclei, positive chemical shift had higher frequencies than the reference. The coupling constants (J) were expressed in $\mathrm{Hz}$; the splitting patterns were designated as $\mathrm{s}$ (singlet), $\mathrm{t}$ (triplet), and $\mathrm{m}$ (multiplet). All the samples were ca. $0.05 \mathrm{M}$.

ESI-MS spectra were recorded on a Finnigan LCQ Deca XP ion trap (Thermo Fisher Scientific, Waltham, Massachusetts USA) using an electrospray ionization (ESI) interface. Complexes were dissolved in methanol or acetonitrile and introduced into the ESI source via a $100 \mu \mathrm{mi}$.d. fused silica capillary using a $500 \mu \mathrm{L}$ syringe. The experimental conditions for spectra, acquired in positive ion mode, were as follows: needle voltage $3.5 \mathrm{kV}$; flow rate 3-5 $\mu \mathrm{L} \mathrm{min}{ }^{-1}$; source temperature $220{ }^{\circ} \mathrm{C} ; \mathrm{m} / \mathrm{z}$ range $50: 2000$; cone potential $43 \mathrm{~V}$; tube lens offset $55 \mathrm{~V}$.

Elemental analyses for $\mathrm{C}$ and $\mathrm{H}$ content were performed at Laboratorio di Chimica Organica, Università di Padova. The tin content was determined in our laboratory, gravimetrically as $\mathrm{SnO}_{2}$, according to Neumann's method [50].

\subsection{Cell Cultures}

Human colon cancer HCT116 and CaCo-2 were cultured in RPMI 1640 medium containing 10\% ( $/ \mathrm{v}$ ) fetal bovine serum (FBS), $2.0 \mathrm{mM}$ glutamine and antibiotic, and antimycotic solution (100 U/mL penicillin, $100 \mu \mathrm{g} / \mathrm{mL}$ streptomycin) in a humidified atmosphere at $37{ }^{\circ} \mathrm{C}$ in the presence of $5 \% \mathrm{CO}_{2}$. For the experiments, cells were seeded at 60-70\% confluence in 96- or 6-well-plates. Cells were then allowed to adhere overnight and subsequently treated with the compounds or vehicle alone. For in vitro experiments, triorganotin(IV) butyrates were dissolved in DMSO and prepared as $10 \mathrm{mM}$ stock solutions, which were opportunely diluted in culture medium prior to use. The final concentration of DMSO in the incubation mixture did not exceed $0.04 \%(v / v)$, which was verified not to affect cellular functions. As a control, equal volumes of DMSO were added to untreated cells.

\subsection{Cell Viability MTT Assay Evaluation}

Cell viability was evaluated by 3-(4,5-dimethylthiazol-2-yl)-2,5-diphenyltetrazolium bromide (MTT) assay, as previously described [16]. Briefly, after treatment in 96-well plates (triplicate wells for each sample), MTT solution (final concentration $1 \mathrm{mg} / \mathrm{mL}$ ) was added for $2 \mathrm{~h}$. The medium was then replaced with lysis buffer $(100 \mu \mathrm{L})$ and the absorbance at $570 \mathrm{~nm}$ (test wavelength) and at $630 \mathrm{~nm}$ (reference wavelength) was measured using an enzyme-linked immune sorbent assay (ELISA) microplate reader (Dynex Technologies, Chantilly, VA, USA). Values reported in the figures are expressed as percentage of the viability of untreated cells and are the means \pm SD of four independent experiments. 


\subsection{Cell Cycle Evaluation}

Cell cycle distribution was measured after cell trypsinization, (0.025\% trypsin-EDTA) cell harvest, washings in PBS, and the addition of a hypotonic solution containing $25 \mu \mathrm{g} / \mathrm{mL}$ propidium iodide, $0.1 \%$ sodium citrate, $0.01 \%$ Nonidet P- 40 , and $10 \mu \mathrm{g} / \mathrm{mL}$ RNase A. The cell cycle phase distribution was evaluated by FacsCanto cytometer (Becton Dickinson, Milan, Italy) using FacsDiva Software (Becton Dickinson, Milan, Italy). Cell debris and aggregates were excluded by opportune gating and 5000 events for each sample were analysed. The results shown in the figure are representative of three independent experiments.

\subsection{Evaluation of Cell Death}

Cell death was assessed by staining the cells with the vital dye Hoechst 33342, which evidences nuclei and allows for the detecting of chromatin condensation and fragmentation. For these experiments, $7 \times 10^{3}$ cells/well were seeded in a 96-well plate, incubated with the compounds for the established times and then stained with Hoechst $(2.5 \mu \mathrm{g} / \mathrm{mL}$ medium) for $30 \mathrm{~min}$. After washings with PBS, cells were visualised using an inverted Leica fluorescent microscope (Leica Microsystems, Wetzlar, Germany) endowed with a 4',6diamidino-2-phenylindole dihydrochloride (DAPI) filter. Leica Q Fluoro Software (Leica Microsystems, Wetzlar, Germany) was used for image acquisition. Annexin V apoptosis detection assay was used to evidence early apoptotic cells. Briefly, $3 \times 10^{5}$ cells were seeded in $6 \mathrm{~cm}$ diameter Petri dishes, allowed to adhere overnight and then treated with the compounds for $24 \mathrm{~h}$. Cells were then harvested, washed twice in PBS, and $10^{5}$ were incubated for 15 min with $5 \mu \mathrm{L}$ annexinV/PI in a $100 \mu \mathrm{L}$ binding buffer. Following dilution (500 $\mu \mathrm{L}$ binding buffer final volume) analysis was performed by flow cytometry using FacsCanto BD. The percentage of annexin V positive cells was evaluated by Flowjo BD Software, Milan, Italy.

\subsection{Western Blotting Analysis}

After treatment, protein extracts were prepared by incubating the cells for $20 \mathrm{~min}$ in an ice-cold lysis buffer supplemented with a protease inhibitor cocktail, as previously reported [51]. After sonication (10 s, three times) and protein quantification by Bradford assay, an equal amount of proteins $(40 \mu \mathrm{g})$ was separated by sodium dodecyl sulphatePolyacrylamide gel electrophoresis (SDS-PAGE) and then electrotransferred to a nitrocellulose membrane for immunodetection. The blots were developed using electrochemical luminescence labeling systems by ChemiDoc, XRS (Bio-Rad, Hercules, CA, USA) Image system. Optical densities of the bands were analysed with Quantity One Imaging Software (Bio-Rad Laboratories). Both Ponceau red staining and immunoblotting for the housekeeping protein $\gamma$-tubulin were considered to verify the correct protein loading. The results shown in the figures are representative of three independent experiments with similar results. Densitometric analysis are reported as the ratio of the intensity of the bands of treated samples to untreated ones after normalization with $\gamma$-tubulin. For acetylated histones, normalization was made with total histone levels.

\subsection{Statistical Analysis}

Data were represented as mean \pm S.D., and analysis was performed using the Student's $t$-test and one-way analysis of variance. Comparisons between the control (untreated) vs. all treated samples were made. If a significant difference was detected by ANOVA analyses, this was re-evaluated by post-hoc Bonferroni's test. GraphPadPrismTM 4.0 Software (Graph PadPrismTM Software Inc., San Diego, CA, USA) was used for statistical calculations. The statistical significance threshold was fixed at $p<0.05$.

\section{Conclusions}

Overall, our results indicate for the first time that tributyltin(IV) butyrate exerts antitumor properties in colon cancer cells. This action is correlated with the G2/M arrest of the cell cycle with consequent ER stress and apoptosis. The compound also exerted 
an epigenetic effect consisting in histone deacetylation, in contrast with butyric acid that instead determined histone acetylation due to HDAC inhibition. Although different mechanisms, such as histone acetyl transferase (HAT) inhibition or a reduced acetyl CoA availability, can account for histone deacetylation, a suggestive hypothesis consists in an opposite behaviour that the butyrate derivative BT2 acquires compared to the parental butyrate, most likely due to HDAC activation (rather than inhibition) by the compound in the conjugated form.

Author Contributions: The chemical part was developed by T.F. and C.P. The Biological study was carried out by A.C., S.E. and M.G.; Conceptualization, S.E., T.F., M.G. and C.P.; methodology, T.F., A.C.; software, A.C., M.G.; validation, M.G., S.E., T.F. and C.P., formal analysis, M.G., S.E., T.F. and C.P.; investi-gation, M.G., S.E., C.P. and T.F.; data curation, M.G., S.E., T.F. writing-original draft preparation, S.E., C.P.; supervision, S.E., T.F. All authors have read and agreed to the published version of the manuscript.

Funding: The Authors gratefully acknowledges the financial support of the Università degli Studi di Palermo, Italy (FFR_D08_PELLERITO, FFR-D15_GIULIANO).

Institutional Review Board Statement: Not applicable.

Informed Consent Statement: Not applicable.

Data Availability Statement: Not applicable.

Acknowledgments: NMR experimental data were provided by ATeN Center-Advanced Technologies Network Center-(Università degli Studi di Palermo, Italy) funded by PON R\&C, Infrastrutture (Progetto PONa3_00273) e del PO FESR, Regione Sicilia-Misura 4.1.2.A.We would like to thank Diana Di Liberto, Dipartimento di Biomedicina, Neuroscienze e Diagnostica avanzata (BIND), Università degli Studi di Palermo for the support in cytofluorimetric analysis; Giovanni Perconti, Institute of Biomedicine and Molecular Immunology “A. Monroy" (IBIM), National Research Council (CNR), Palermo, Italy, for kindly providing eIF2 $\alpha$ antibody and Vincenzo Cavalieri, Laboratory of Molecular Biology and Functional Genomics, Department of Biological, Chemical and Pharmaceutical Sciences and Technologies (STEBICEF), University of Palermo, Palermo, Italy, for kindly providing Histone H3 antibody.

Conflicts of Interest: The authors declare no conflict of interest.

Sample Availability: Samples of triorganotin(IV) butyrates are available from the authors.

\section{References}

1. Pellerito, L. Organotin(IV) $\mathrm{n}+$ complexes formed with biologically active ligands: Equilibrium and structural studies, and some biological aspects. Coord. Chem. Rev. 2002, 224, 111-150. [CrossRef]

2. Gielen, M. Review: Organotin compounds and their therapeutic potential: A report from the Organometallic Chemistry Department of the Free University of Brussels. Appl. Organometal. Chem. 2002, 16, 481-494. [CrossRef]

3. Sirajuddin, M.; Ali, S. Organotin(IV) Carboxylates as Promising Potential Drug Candidates in the Field of Cancer Chemotherapy. CPD 2017, 22, 6665-6681. [CrossRef] [PubMed]

4. Bajka, B.H.; Clarke, J.M.; Cobiac, L.; Topping, D.L. Butyrylated starch protects colonocyte DNA against dietary protein-induced damage in rats. Carcinogenesis 2008, 29, 2169-2174. [CrossRef] [PubMed]

5. Corfe, B.M.; Williams, E.A.; Bury, J.P.; Riley, S.A.; Croucher, L.J.; Lai, D.Y.; Evans, C.A. A study protocol to investigate the relationship between dietary fibre intake and fermentation, colon cell turnover, global protein acetylation and early carcinogenesis: The FACT study. BMC Cancer 2009, 9, 332. [CrossRef]

6. Le Leu, R.K.; Hu, Y.; Brown, I.L.; Young, G.P. Effect of high amylose maize starches on colonic fermentation and apoptotic response to DNA-damage in the colon of rats. Nutr. Metab. 2009, 6, 11. [CrossRef]

7. Hamer, H.M.; Jonkers, D.; Venema, K.; Vanhoutvin, S.; Troost, F.J.; Brummer, R.-J. Review article: The role of butyrate on colonic function. Aliment. Pharmacol. Ther. 2007, 27, 104-119. [CrossRef]

8. Cahours, A. Untersuchungen über die metallhaltigen organischen Radicale. Ann. Chem. Pharm. 1860, 114, 227-255. [CrossRef]

9. Caseri, W. Initial organotin chemistry. J. Organomet. Chem. 2014, 751, 20-24. [CrossRef]

10. Nath, M.; Vats, M.; Roy, P. Mode of action of tin-based anti-proliferative agents: Biological studies of organotin(IV) derivatives of fatty acids. J. Photochem. Photobiol. B Biol. 2015, 148, 88-100. [CrossRef] 
11. Di Stefano, R.; Scopelliti, M.; Pellerito, C.; Casella, G.; Fiore, T.; Stocco, G.C.; Vitturi, R.; Colomba, M.; Ronconi, L.; Sciacca, I.D. Organometallic complexes with biological molecules. XVIII. Alkyltin(IV) cephalexinate complexes: Synthesis, solid state and solution phase investigations. J. Inorg. Biochem. 2004, 98, 534-546. [CrossRef] [PubMed]

12. Pellerito, C.; D'Agati, P.; Fiore, T.; Mansueto, C.; Mansueto, V.; Stocco, G.; Nagy, L.; Pellerito, L. Synthesis, structural investigations on organotin(IV) chlorin-e6 complexes, their effect on sea urchin embryonic development and induced apoptosis. J. Inorg. Biochem. 2005, 99, 1294-1305. [CrossRef] [PubMed]

13. Pellerito, O.; Prinzivalli, C.; Foresti, E.; Sabatino, P.; Abbate, M.; Casella, G.; Fiore, T.; Scopelliti, M.; Pellerito, C.; Giuliano, M.; et al. Synthesis, chemical characterization and biological activity of new histone acetylation/deacetylation specific inhibitors: A novel and potential approach to cancer therapy. J. Inorg. Biochem. 2013, 125, 16-25. [CrossRef] [PubMed]

14. Abbate, M.; Casella, G.; Fiore, T.; Grasso, G.; Pellerito, C.; Scopelliti, M.; Spinella, A.; Pellerito, L. Structural characterization of triorganotin(IV) complexes with sodium fusidate and DFT calculations. J. Organomet. Chem. 2010, 695, 1405-1413. [CrossRef]

15. Pellerito, C.; Morana, O.; Ferrante, F.; Calvaruso, G.; Notaro, A.; Sabella, S.; Fiore, T. Synthesis, chemical characterization, computational studies and biological activity of new DNA methyltransferases (DNMTs) specific inhibitor. Epigenetic regulation as a new and potential approach to cancer therapy. J. Inorg. Biochem. 2015, 150, 18-27. [CrossRef]

16. Pellerito, C.; Emanuele, S.; Ferrante, F.; Celesia, A.; Giuliano, M.; Fiore, T. Tributyltin(IV) ferulate, a novel synthetic ferulic acid derivative, induces autophagic cell death in colon cancer cells: From chemical synthesis to biochemical effects. J. Inorg. Biochem. 2020, 205, 110999. [CrossRef]

17. Liu, H.; Wang, J.; He, T.; Becker, S.; Zhang, G.; Li, D.; Ma, X. Butyrate: A Double-Edged Sword for Health? Adv. Nutr. 2018, 9 , 21-29. [CrossRef] [PubMed]

18. Lee, Y.; Shin, H.; Kim, J.-H. Change in gene expression profiles of secreted frizzled-related proteins (SFRPs) by sodium butyrate in gastric cancers: Induction of promoter demethylation and histone modification causing inhibition of Wnt signaling. Int. J. Oncol. 2012, 40, 1533-1542. [CrossRef]

19. Frew, A.J.; Johnstone, R.W.; Bolden, J.E. Enhancing the apoptotic and therapeutic effects of HDAC inhibitors. Cancer Lett. 2009, 280, 125-133. [CrossRef]

20. Geng, H.-W.; Yin, F.-Y.; Zhang, Z.-F.; Gong, X.; Yang, Y. Butyrate Suppresses Glucose Metabolism of Colorectal Cancer Cells via GPR109a-AKT Signaling Pathway and Enhances Chemotherapy. Front. Mol. Biosci. 2021, 8, 634874. [CrossRef] [PubMed]

21. Mrkvicova, A.; Chmelarova, M.; Peterova, E.; Havelek, R.; Baranova, I.; Kazimirova, P.; Rudolf, E.; Rezacova, M. The effect of sodium butyrate and cisplatin on expression of EMT markers. PLoS ONE 2019, 14, e0210889. [CrossRef]

22. Ramos, M.G.; Rabelo, F.L.A.; Brumatti, G.; Bueno-da-Silva, A.E.; Amarante-Mendes, G.P.; Alvarez-Leite, J.I. Butyrate Increases Apoptosis Induced by Different Antineoplastic Drugs in Monocytic Leukemia Cells. Chemotherapy 2004, 50, 221-228. [CrossRef] [PubMed]

23. Shetty, M.G.; Pai, P.; Deaver, R.E.; Satyamoorthy, K.; Babitha, K.S. Histone deacetylase 2 selective inhibitors: A versatile therapeutic strategy as next generation drug target in cancer therapy. Pharmacol. Res. 2021, 170, 105695. [CrossRef] [PubMed]

24. Han, H.; Feng, F.; Li, H. Research advances on epigenetics and cancer metabolism. J. Zhejiang Univ. Med. Sci. 2021, 50, 1-16. [CrossRef] [PubMed]

25. Sun, L.; Zhang, H.; Gao, P. Metabolic reprogramming and epigenetic modifications on the path to cancer. Protein Cell 2021. [CrossRef]

26. Osada, S.; Nishikawa, J.; Nakanishi, T.; Tanaka, K.; Nishihara, T. Some organotin compounds enhance histone acetyltransferase activity. Toxicol. Lett. 2005, 155, 329-335. [CrossRef]

27. Hanaoka, S.; Ishida, K.; Tanaka, S.; Sakamoto, S.; Okuda, K.; Sanoh, S.; Ohta, S.; Kotake, Y. Tributyltin induces epigenetic changes and decreases the expression of nuclear respiratory factor-1. Metallomics 2018, 10, 337-345. [CrossRef]

28. Wang, Y.; Wang, C.; Zhang, J.; Chen, Y.; Zuo, Z. DNA hypomethylation induced by tributyltin, triphenyltin, and a mixture of these in Sebastiscus marmoratus liver. Aquat. Toxicol. 2009, 95, 93-98. [CrossRef]

29. Kristeleit, R.; Stimson, L.; Workman, P.; Aherne, W. Histone modification enzymes: Novel targets for cancer drugs. Expert Opin. Emerg. Drugs 2004, 9, 135-154. [CrossRef]

30. Vigushin, D.M.; Coombes, R.C. Histone deacetylase inhibitors in cancer treatment. Anti Cancer Drugs 2002, 13, 1-13. [CrossRef]

31. Andrade, F.D.O.; Furtado, K.S.; Heidor, R.; Sandri, S.; Hebeda, C.B.; Miranda, M.L.P.; Fernandes, L.H.G.; Yamamoto, R.C.; Horst, M.A.; Farsky, S.H.P.; et al. Antiangiogenic effects of the chemopreventive agent tributyrin, a butyric acid prodrug, during the promotion phase of hepatocarcinogenesis. Carcinogenesis 2019, 40, 979-988. [CrossRef]

32. Deacon, G. Relationships between the carbon-oxygen stretching frequencies of carboxylato complexes and the type of carboxylate coordination. Coord. Chem. Rev. 1980, 33, 227-250. [CrossRef]

33. Deacon, G.B.; Huber, F.; Phillips, R.J. Diagnosis of the nature of carboxylate coordination from the direction of shifts of carbon oxygen stretching frequencies. Inorg. Chim. Acta 1985, 104, 41-45. [CrossRef]

34. Nath, M.; Vats, M.; Roy, P. Tri- and diorganotin(IV) complexes of biologically important orotic acid: Synthesis, spectroscopic studies, in vitro anti-cancer, DNA fragmentation, enzyme assays and in vivo anti-inflammatory activities. Eur. J. Med. Chem. 2013, 59, 310-321. [CrossRef]

35. Nath, M.; Vats, M.; Roy, P. Design, spectral characterization, anti-tumor and anti-inflammatory activity of triorganotin(IV) hydroxycarboxylates, apoptosis inducers: In vitro assessment of induction of apoptosis by enzyme, DNA-fragmentation, acridine orange and comet assays. Inorg. Chim. Acta 2014, 423, 70-82. [CrossRef] 
36. Whiffen, D.H. 273. Vibrational frequencies and thermodynamic properties of fluoro-, chloro-, bromo-, and iodo-benzene. J. Chem. Soc. 1956, 1350-1356. [CrossRef]

37. Lockhart, T.P.; Manders, W.F. Structure determination by NMR spectroscopy. Dependence of $|2 J(119 S n, 1 \mathrm{H})|$ on the Me-Sn-Me angle in methyltin(IV) compounds. Inorg. Chem. 1986, 25, 892-895. [CrossRef]

38. Lockhart, T.P.; Manders, W.F. Solid-state carbon-13 NMR investigation of methyltin(IV) compounds. Correlation of NMR parameters with molecular structure. J. Am. Chem. Soc. 1987, 109, 7015-7020. [CrossRef]

39. Holeček, J.; Lyčka, A. Dependence of $\left[{ }^{1} \mathrm{~J}\left({ }^{119} \mathrm{Sn}^{13} \mathrm{C}\right)\right]$ on the $\mathrm{C}-\mathrm{Sn}-\mathrm{C}$ angle in n-butyltin(IV) compounds. Inorg. Chim. Acta 1986, 118, L15-L16. [CrossRef]

40. Holeček, J.; Nádvorník, M.; Handlíř, K.; Lyčka, A. 13C and 119Sn NMR Study of some four- and five-coordinate triphenyltin(IV) compounds. J. Organomet. Chem. 1983, 241, 177-184. [CrossRef]

41. Baul, T.S.B.; Masharing, C.; Basu, S.; Rivarola, E.; Holčapek, M.; Jirásko, R.; Lyčka, A.; de Vos, D.; Linden, A. Synthesis, characterization, cytotoxic activity and crystal structures of tri- and di-organotin(IV) complexes constructed from the $\beta-\{[(E)-1-$ (2-hydroxyaryl)alkylidene]amino\}propionate and $\beta$ - $\{[(2 Z)-(3$-hydroxy-1-methyl-2-butenylidene)]amino\}propionate skeletons. J. Organomet. Chem. 2006, 691, 952-965. [CrossRef]

42. Baul, T.S.B.; Singh, K.S.; Holčapek, M.; Jirásko, R.; Rivarola, E.; Linden, A. Synthesis, characterization and crystal structures of polymeric and dimeric triphenyltin(IV) complexes of 4-[((E)-1-\{2-hydroxy-5-[(E)-2-(2-carboxyphenyl)-1-diazenyl]phenyl\} methylidene)amino]aryls. J. Organomet. Chem. 2005, 690, 4232-4242. [CrossRef]

43. Cao, M.; Zhang, Z.; Han, S.; Lu, X. Butyrate inhibits the proliferation and induces the apoptosis of colorectal cancer HCT116 cells via the deactivation of mTOR/S6K1 signaling mediated partly by SIRT1 downregulation. Mol. Med. Rep. 2019, 19, 3941-3947. [CrossRef] [PubMed]

44. Lallemand, F.; Courilleau, D.; Buquet-Fagot, C.; Atfi, A.; Montagne, M.-N.; Mester, J. Sodium Butyrate Induces G2 Arrest in the Human Breast Cancer Cells MDA-MB-231 and Renders Them Competent for DNA Rereplication. Exp. Cell Res. 1999, 247, 432-440. [CrossRef]

45. Lee, D.; Hokinson, D.; Park, S.; Elvira, R.; Kusuma, F.; Lee, J.-M.; Yun, M.; Lee, S.-G.; Han, J. ER Stress Induces Cell Cycle Arrest at the G2/M Phase Through eIF2 $\alpha$ Phosphorylation and GADD45 $\alpha$. Int. J. Mol. Sci. 2019, 20, 6309. [CrossRef]

46. Chaitanya, G.; Alexander, J.S.; Babu, P. PARP-1 cleavage fragments: Signatures of cell-death proteases in neurodegeneration. Cell Commun. Signal. 2010, 8, 31. [CrossRef]

47. Donohoe, D.R.; Collins, L.B.; Wali, A.; Bigler, R.; Sun, W.; Bultman, S.J. The Warburg Effect Dictates the Mechanism of ButyrateMediated Histone Acetylation and Cell Proliferation. Mol. Cell 2012, 48, 612-626. [CrossRef]

48. Li, Y.; Wang, F.; Chen, X.; Wang, J.; Zhao, Y.; Li, Y.; He, B. Zinc-dependent Deacetylase (HDAC) Inhibitors with Different Zinc Binding Groups. Curr. Top. Med. Chem. 2019, 19, 223-241. [CrossRef]

49. Gottlieb, H.E.; Kotlyar, V.; Nudelman, A. NMR Chemical Shifts of Common Laboratory Solvents as Trace Impurities. J. Org. Chem. 1997, 62, 7512-7515. [CrossRef]

50. Neumann, W.P. The Organic Chemistry of Tin; The Chemistry of Organometallic Compounds: London, UK; Interscience: New York, NY, USA, 1970; ISBN 978-0-471-63237-5.

51. Notaro, A.; Emanuele, S.; Geraci, F.; D’Anneo, A.; Lauricella, M.; Calvaruso, G.; Giuliano, M. WIN55, 212-2-Induced Expression of Mir-29b1 Favours the Suppression of Osteosarcoma Cell Migration in a SPARC-Independent Manner. Int. J. Mol. Sci. 2019, 20, 5235. [CrossRef] 